\title{
Uji Korelasi dan Analisis Lintas Terhadap Karakter Komponen Pertumbuhan dan Karakter Hasil Tanaman Tomat (Lycopersicum esculentum, Mill)
}

Maria Afnita Lelang a

${ }^{a}$ Fakultas Pertanian, Universitas Timor, Kefamenanu, TTU - NTT, Indonesia.

\section{Article Info}

\section{Article history:}

Received 1 Januari 2017

Received in revised form 20 Februari 2017 Accepted 22 Maret 2017

\section{Keywords:}

Korelasi

Pengaruh langsung

Pengaruh tidak langsung

Tomat

\begin{abstract}
Abstrak
Uji Korelasi dan analisis lintas bertujuan untuk mendapatkan komponen karakter pertumbuhan dan komponen hasil yang dapat digunakan sebagai kriteria seleksi pada tanaman tomat. Penelitian ini dilakukan pada bulan Februari dan Mei 2015. Rancangan penelitian yang digunakan adalah Rancangan Petak Terbagi (Split Plot Design) pola faktorial $3 \times 3$ yang diulang tiga kali. Faktor utama adalah jenis pupuk (J), yang terdiri dari tiga tingkatan, yaitu kotoran ayam (J1), kotoran sapi (J2) dan kotoran kambing (J3). Faktor kedua adalah aplikasi pupuk (C), yang terdiri tebar (C1), pop-up (C2) dan fertigasi (C3). Petak yang digunakan berukuran $2 \mathrm{mx}$ 1,5 m, jarak tanam 40 $\mathrm{cm}$ x $30 \mathrm{~cm}$ dan menanam satu biji per lubang. Hasil korelasi dan analisis lintas menunjukkan bahwa karakter yang mempunyai nilai pengaruh langsung yang positif, bertanda sama dengan nilai korelasi serta memiliki selisih yang kecil yaitu jumlah buah per petak dan indeks panen.@2017 dipublikasikan oleh Savana Cendana.
\end{abstract}

\section{Pendahuluan}

Peningkatan produksi tanaman tomat dapat dilakukan dengan perbaikan teknik budidaya. Tujuan pemuliaan tanaman tomat adalah merakit atau mendapatkan tanaman tomat yang berdaya hasil tinggi, berkualitas serta resisten terhadap hama dan penyakit. Perakitan varietas pada pemuliaan tanaman dapat dilakukan melalui seleksi secara langsung terhadap daya hasil atau tidak langsung melalui beberapa karakter lain yang terkait dengan daya hasil (Singh dan Chaudhary, 1985).

Karakter daya hasil merupakan karakter kompleks yang sangat dipengaruhi oleh karakter pertumbuhan dan karakter komponen hasil (Allard, 1960). Keeratan hubungan antar karakter tersebut dapat diketahui dengan analisis korelasi. Metode ini sangat bermanfaat dalam program pemuliaan tanaman untuk mengetahui ada tidaknya hubungan antara karakter yang ada dengan karakter utama yaitu hasil, sehingga berguna untuk memperbaiki respon ikutan (correlated respon) (Falconer dan Mackay, 1996). Pengembangan dari analisis korelasi adalah analisis lintas. Analisis lintas merupakan bentuk analisis regresi linear terstruktur yang memperlihatkan hubungan dan pengaruh antar karakter, baik pengaruh langsung (direct effect) maupun pengaruh tidak langsung (indirect effect) melalui karakter lain (Singh dan Chaudhary, 1985). Analisi lintas memberikan informasi keeratan hubungan antar karakter dan menjelaskan mekanisme hubungan kausal antar karakter melalui lintasan-lintasan terpisah yang dibangun dalam diagram lintas (Li, 1956). Haydar et al. (2007) dalam penelitiannya menguraikan bahwa tinggi tanaman pada saat berbunga dan jumlah bunga merupakan karakter yang paling penting kontribusinya terhadap hasil tomat.

Penggunaan analisis korelasi dan sidik lintas sangat bermanfaat dalam mempelajari keeratan hubungan karakter kuantitatif dan sebagai dasar perencanaan program seleksi yang lebih efisien (Rahman et al, 2002; Wirnas et al. 2006; Arsyad et al. 2007; Nasution 2010).

\section{Metode}

Percobaan dilaksanakan bulan Februari hingga Mei 2015 di kebun Fakultas Pertanian, Universitas Timor, Kelurahan Sasi, Kecamatan Kota Kefamenanu, Kabupaten TTU. Bahan tanam yang digunakan adalah varietas Lentana. Media persemaian yang digunakan adalah campuran tanah (top soil) dan pasir dan pupuk kandang dengan perbandingan $1: 1: 1$. Umur pemindahan bibit dari persemaian ke bedengan percobaan adalah $30 \mathrm{HST}$.

Persiapan lahan dilakukan sebelum penanaman dengan membuat lahan menjadi petakan berukuran $2 \mathrm{~m}$ x 1,5 $\mathrm{m}$. Lahan terbagi atas 3 ulangan, tiap ulangan terdapat 9 petakan sesuai dengan jumlah perlakuan. Pemupukan dilakukan pada pada awal persiapan lahan sebelum penanaman. Pupuk kandang yang digunakan adalah pupuk ayam dengan dosis $20 \mathrm{t} / \mathrm{ha}$

Penanaman bibit diletakan dalam tubang tanam yang telah disiapkan dalam bedeng percobaan dengan diameter $15 \mathrm{~cm}$ sedalam $15 \mathrm{~cm}$ menggunakan jarak tanam $40 \times 30 \mathrm{~cm}$. populasi tanaman dalam anak petak sebanyak 25 tanaman dengan demikian total populasinya sebanyak 675 tanaman untuk 27 bedeng percobaan.

Penyiraman dilakukan setiap pagi dan sore hari. Penyulaman dilakukan pada tanaman yang kurang baik pertumbuhannya setelah 14 HST. Penyiangan dengan mencabut gulma yang ada. Panen dilakukan pada 60 - 110 hari atau disesuaikan dengan kondisi pertanaman di lapangan, dilakukan secara serentak atau per ulangan pada hari berbeda dalam minggu yang sama.

Pengamatan peubah kuantitaif dilakukan terhadap petak (4 m x $3 \mathrm{~m})$, ubinan $(1 \mathrm{~m} \mathrm{x} 1 \mathrm{~m})$, dan 5 tanaman contoh yaitu tinggi tanaman $(\mathrm{cm})$, diameter batang $(\mathrm{mm})$, luas daun $\left(\mathrm{cm}^{3}\right)$, diameter buah $(\mathrm{mm})$, berat per buah $(\mathrm{g})$, jumlah buah per tanaman, berat buah per tanaman $(\mathrm{kg})$, jumlah buah per anak petak, berat buah per anak petak ( $\mathrm{t} / \mathrm{ha})$, berat segar berangkasan $(\mathrm{t} / \mathrm{ha})$, berat kering berangkasan (t/ha) dan indeks panen $(\%)$

Data kuantitatif dianalisis dengan analisis korelasi dilanjutkan dengan menggunakan analisis lintas untuk mencari karakter yang berpengaruh langsung dan tidak langsung pada berat buah per anaka petak.
1. Nilai korelasi dihitung dengan menggunakan rumus (Walpole 1993) :

$$
r=\frac{\sum X Y-\frac{\sum X \sum Y}{n}}{\sqrt{\left(\sum \mathrm{x}^{2}-\frac{\left(\sum \mathrm{x}\right)^{2}}{\mathrm{n}}\right)\left(\sum \mathrm{Y}^{2}-\frac{\left(\sum \mathrm{Y}\right)^{2}}{\mathrm{n}}\right)}}
$$

2. Perhitungan Analisis Lintasan (Singh dan Chaudary, 1979) :

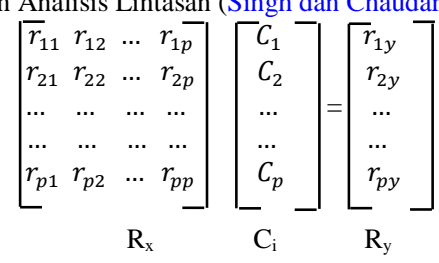

Nilai $C_{i}$ (pengaruh langsung) dapat dihitung menggunakan rumus sebagai berikut

$$
C_{i}=R_{x}^{-1} R_{y}
$$

Dimana :

$\mathrm{R}_{\mathrm{x}}=$ Matriks korelasi antar peubah bebas $; R_{x}^{-1}=$ Invers matriks $\mathrm{R}_{\mathrm{x}}$

Vektor koefisien lintasan yang menunjukkan pengaruh

$\mathrm{C}_{\mathrm{i}}=$ langsung setiap peubah bebas yang telah dibakukan terhadap peubah tak bebas

$\mathrm{R}_{\mathrm{y}}=$ Vektor koefisien korelasi antara peubah bebas $\mathrm{X}_{\mathrm{i}}(\mathrm{i}=1,2, \ldots . \mathrm{p})$ dengan peubah tak bebas $\mathrm{Y}$

Apabila koefisien lintas $\mathrm{C}_{\mathrm{i}}$ telah diperoleh, maka beberapa informasi penting akan diperoleh berdasarkan metode analisis lintas antara lain seperti 1). Pengaruh langsung variabel bebas yang dibakukan, terhadap variabel tak bebas $Y$, diukur oleh koefisien lintas $C_{i} .2$ ). Pengaruh tidak langsung variabel bebas $\mathrm{Z}_{\mathrm{i}}$ terhadap variabel tak bebas $\mathrm{Y}$, melalui variabel bebas $\mathrm{Z}_{\mathrm{j}}$ (melalui kehadiran variabel bebas $Z_{j}$ dalam model) diukur dengan besaran $C_{j} \cdot r_{i j} .3$ ). Pengaruh galat atau error atau sisaan atau residual yang tak dapat dijelaskan oleh model analisis lintas. Pengaruh-pengaruh yang tidak dapat dijelaskan oleh suatu model dimasukkan sebagai pengaruh galat atau sisaan yang diukur nilainya dengan rumus:

$$
C_{s}^{2}=1-\sum C_{i} r_{i j} \underset{\mathrm{i}=1}{\mathrm{p}} \operatorname{dimana} C_{s}=\sqrt{C_{s}^{2}}
$$

Apabila nilai korelasi antara faktor penyebab dan akibat hampir sama besarnya dengan pengaruh langsungnya (perbedaannya tidak lebih dari 0.05 ) maka koefisien tersebut menjelaskan hubungan yang sebenarnya dan seleksi langsung terhadap variabel tersebut akan sangat efektif (Allard, 1960). Penentuan karakter-karakter yang dapat dijadikan sebagai kriteria seleksi yang efektif dapat dilihat dari besarnya pengaruh langsung terhadap hasil (Ci), korelasi antara karakter dengan hasil (rih) dan selisih antara korelasi antar karakter dan hasil dengan pengaruh langsung karakter tersebut terhadap hasil (rih-Ci) $<0.05$. Jika ketiga hal tersebut dipenuhi, maka karakter tersebut sangat efektif sebagai kriteria seleksi untuk menduga hasil.

\section{Hasil dan Pembahasan}

3.1 Korelasi Karakter Agronomi dengan Karakter Berat Buah Per Anak Petak

Nilai korelasi (r) berada antara -1 hingga +1 , nilai nol menunjukkan tidak ada hubungan antara kedua peubah (Allard 1960; Gomez dan Gomes 1995; Mattik dan Sumertajaya 2006; Priyatno 2009). Hubungan signifikansi menerangkan tentang kesahihan hubungan antara dua variabel berdasarkan pada taraf kepercayaan yang diambil (5\% atau 1\%). Nilai korelasi yang nyata berarti adanya hubungan yang kuat, bukan karena adanya peluang tetapi benarbenar hubungan yang nyata antara dua variabel tersebut (Siregar, 2013). 
Pendugaan analisis koralasi bertujuan untuk mempelajari pola hubungan karakter komponen hasil dan hasil dan menyeleksi karakter-karakter yang berkorelasi dengan karakter hasil. Hasil merupakan tujuan perbaikan dalam program pemuliaan tanaman. Kombinasi karakter seleksi antara karakter hasil dan komponennya dapat meninggkatkan kemajuan genetik dan dan daya hasil pada tomat.

Nilai koefisien korelasi yang menunjukkan keeratan hubungan antar karakter agronomi pada tomat dapat dilihat pada Tabel 1. Karakter jumlah buah per anak petak dan karakter indeks panen berkorelasi positif dan sangat nyata dengan karakter berat buah per anak petak dengan masing- masing nilai $\mathrm{r}=$ $0.999, \mathrm{p}=<0.000$ dan $\mathrm{r}=0,900, \mathrm{p}=0,002$. Singh dan Chaudhary (1985) menyatakan bahwa hubungan dua variabel atau lebih dinyatakan positif bila nilai suatu variabel ditingkatkan, maka akan meningkatkan variabel yang lain. Oleh karenanya peningkatan satu sifat kadang diikuti peningkatan sifat yang lainnya. Dengan demikian jika karakter jumlah buah per anak petak dan indeks panen di tingkatkan maka akan meningkatkan berat buah per anak petak.

Karakter tinggi tanaman berkorelasi negatif dan sangat nyata dengan jumlah buah per tanaman dengan nilai $r=-0.000$ dan $\mathrm{p}=0.955$ serta karakter diameter berkorelasi negatif dan sangat nyata dengan berat per buah dengan nilai $r=-0.008$ dan $\mathrm{p}=0.425$. Hal ini menunjukkan bahwa penambahan tinggi tanaman akan menurunkan jumlah buah per tanaman. Korelasi negatif tersebut adalah karena peran antagonis dari tinggi tanaman terhadap jumlah buah per tanaman dan diameter buah terhadap berat per buah. Pertumbuhan vegetatif mengakibatkan translokasi fotositat ke buah menjadi berkurang. Kapasitas fotosintesis berkurang dan akibatnya daya hasilnya lebih rendah. Karakter tinggi tanaman dan diameter buah tidak dapat digunakan untuk menduga berat buah per anak petak pada tanaman tomat.

\begin{tabular}{|c|c|c|c|c|c|c|c|c|c|c|c|}
\hline \multicolumn{2}{|c|}{$\begin{array}{l}\text { Karakter } \\
\text { Agonomi }\end{array}$} & TT & DB & JBPT & DH & BBPT & BPB & JBPP & BSBr & BKBr & IP \\
\hline \multirow{2}{*}{ DB } & $\mathrm{R}$ & 0.690 & & & & & & & & & \\
\hline & Sig. & $0.058^{*}$ & & & & & & & & & \\
\hline \multirow{2}{*}{ JBPT } & $\mathrm{R}$ & -0.024 & -0.323 & & & & & & & & \\
\hline & Sig. & $0.955 * *$ & 0.435 & & & & & & & & \\
\hline \multirow{2}{*}{ DH } & $\mathrm{R}$ & \begin{tabular}{|l|}
-0.008 \\
\end{tabular} & -0.277 & 0.503 & & & & & & & \\
\hline & Sig. & 0.986 & 0.507 & 0.204 & & & & & & & \\
\hline \multirow{2}{*}{ BBPT } & $\mathrm{R}$ & 0.689 & 0.795 & -0.234 & -0.474 & & & & & & \\
\hline & Sig. & 0.059 & $0.018^{* * *}$ & 0.576 & 0.235 & & & & & & \\
\hline \multirow{2}{*}{ BPB } & $\mathrm{R}$ & -0.477 & -0.006 & -0.471 & -0.330 & -0.217 & & & & & \\
\hline & Sig. & 0.232 & 0.988 & $0.239^{*}$ & $0.425^{* *}$ & 0.605 & & & & & \\
\hline \multirow{2}{*}{ JBPP } & $\mathrm{R}$ & -0.616 & -0.660 & 0.015 & -0.008 & -0.566 & -0.218 & & & & \\
\hline & Sig. & 0.104 & 0.075 & 0.973 & 0.985 & 0.144 & 0.605 & & & & \\
\hline \multirow{2}{*}{$\mathrm{BSBr}$} & $\mathrm{R}$ & -0.216 & -0.522 & 0.619 & -0.120 & -0.237 & -0.397 & 0.482 & & & \\
\hline & Sig. & $0.608^{*}$ & 0.184 & 0.102 & 0.776 & 0.572 & 0.330 & 0.226 & & & \\
\hline \multirow{2}{*}{$\mathrm{BKBr}$} & $\mathrm{R}$ & -0.020 & -0.538 & 0.692 & 0.195 & -0.183 & -0.703 & 0.441 & $0.885^{* *}$ & & \\
\hline & Sig. & 0.963 & 0.169 & 0.057 & 0.644 & 0.665 & 0.052 & 0.274 & 0.003 & & \\
\hline \multirow{2}{*}{ IP } & $\mathrm{R}$ & -0.622 & -0.429 & -0.235 & -0.174 & -0.523 & 0.064 & $0.894 * *$ & 0.203 & 0.047 & \\
\hline & Sig. & 0.100 & 0.288 & $0.575^{* *}$ & $0.680^{*}$ & 0.183 & 0.880 & 0.003 & 0.629 & 0.913 & \\
\hline \multirow{2}{*}{ BBPP } & $\mathrm{R}$ & -0.616 & -0.660 & 0.006 & -0.026 & -0.566 & -0.206 & $0.999^{* *}$ & 0.484 & 0.434 & $0.900 *$ \\
\hline & Sig. & \begin{tabular}{|l|}
0.104 \\
\end{tabular} & 0.075 & 0.989 & 0.951 & 0.144 & 0.624 & $<.0001$ & 0.224 & 0.282 & 0.002 \\
\hline \multicolumn{12}{|c|}{$\begin{array}{l}\text { Keterangan : } \\
{ }^{* *} \text { berbeda nyata pada } \alpha 0.01 \text { dan }{ }^{\text {tn }} \text { berbeda nyata pada } \alpha 0.05, \mathrm{r}=\text { korelasi }\end{array}$} \\
\hline $\mathrm{TT}$ & \multicolumn{3}{|c|}{ Tinggi tanaman } & BPB & $: \quad$ Berat & er buah & & & & & \\
\hline DB & \multirow{2}{*}{\multicolumn{3}{|c|}{$\begin{array}{l}\text { Diameter batang } \\
\text { Jumlah buah per tanaman }\end{array}$}} & JBPP & Jumla & buah per a & ak petak & & & & \\
\hline JBPT & : & \multirow{2}{*}{\multicolumn{2}{|c|}{$\begin{array}{l}\text { Jumlah buah per tanaman } \\
\text { Diameter buah }\end{array}$}} & $\mathrm{BSBr}$ & Berat & egar berang & & & & & \\
\hline DH & : & & & IP & Indek & anen & & & & & \\
\hline BBPT & : & \multicolumn{2}{|c|}{ Berat buah per tanaman } & BBPP & Berat & uah per ana & petak & & & & \\
\hline
\end{tabular}

Karakter-karakter yang mempunyai hubungan yang sangat erat adalah jumlah buah per anak petak berkorelasi positif dan sangat nyata dengan indeks panen dengan nilai $r=0.894$ dan $p=0.003$. Indeks panen dihitung dengan cara membandingkan berat bagian tanaman yang bernilai ekonomis (berat buah per anak petak) dengan berat bagian seluruh tanaman. Berat segar berangkasan berkorelasi positif dan sangat nyata dengan berat kering berangkasan dengan nilai $r=0.885$ dan $p=0.003$. Hal ini menunjukkan bahwa semakin tinggi berat segar berangkasan semakin tinggi berat kering berangkasan yang diperoleh, karena berak kering berupakan berangkasan segar yang dikeringkan atau di kurangi kadar airnya. Menurut Gani et al. (1995) menyatakan bahwa, walaupun angka-angka korelasi relatif tinggi, belum dapat dikatakan bahwa suatu karakter berperan terhadap karakter hasil. Hal ini terutama disebabkan pengujian yang tidak bersifat multilokasi.

Korelasi yang tinggi hanya menunjukkan keeratan hubungan antar sifat tetapi tidak dapat menunjukkan adanya hubungan sebab akibat. Analisis lintas dapat dimanfaatkan untuk mengetahui hubungan sebab akibat dan dapat memilahnya menjadi pengaruh langsung dan tidak langsung (Li, 1956).

\subsection{Analisis Lintas Berat Buah Per Anak Petak}

Analisis koefisien lintas (path-coefisien analysis) mampu menjelaskan konstribusi relatif dari komponen tumbuh dan komponen hasil terhadap hasil, baik langsung maupun tidak langsung (Tabel 2). Metode ini memecah koefisien korelasi antara masing-masing karakter yang dikorelasikan dengan hasil menjadi dua komponen, yaitu pengaruh langsung dan pengaruh tidak langsung, sehingga hubungan kausal di antara karakter yang dikorelasikan dapat diketahui (Ambarwati dan Murti 2001; Mohammadi et al. 2003). Karakter agronomi seperti tinggi tanaman, diameter batang, diameter buah, jumlah buah per tanaman, berat buah per tanaman, berat per buah, berat segar berangkasan dan berat kering berangkasan adalah karakter yang tidak disertakan pada analisis lintas. Hal ini disebabkan karakter-karakter tersebut tidak berkorelasi dengan berat buah per anak petak $(\mathrm{P}>0.05)$ berdasarkan uji Pearson correlation.

Pengaruh langsung yang besar hanya pada karakter jumlah buah per anak petak yaitu 0.968) dan indeks panen yaitu 0.03. Pengaruh langsung terbesar disumbangkan jumlah buah per anak petak demikian juga dengan jumlah pengaruh total koefisien lintas karakter jumlah buah per anak petak memiliki nilai total terbesar yaitu (0.999). Hal ini menunjukkan bahwa karakter tersebut paling berpengaruh terhadap karakter berat buah per anak petak. Pengaruh variabel bebas (independent) yang mempunyai pengaruh langsung terbesar terhadap variabel terikat (dependent) adalah sebesar $\mathrm{C}$ (pengaruh langsung) dapat diinterpretasikan bahwa setiap kenaikan satu simpangan baku dalam nilai independent secara rata-rata akan meningkatkan nilai dependent sebesar C simpanan baku (Sugiyono 2013). Dengan demikian, pengaruh langsung jumlah buah per anak petak berat buah per anak petak adalah sebesar 0.986 dapat diinterpretasikan bahwa setiap kenaikan satu simpangan baku dalam nilai jumlah buah per anak petak secara rata-rata akan meningkatkan nilai berata buah per anak petak sebesar 0.986 simpanan baku.

Tabel 2. Nilai Pengaruh Langsung Dan Tidak Langsung Karakter Agronomi Pada Tanaman Tomat

\begin{tabular}{|c|c|c|c|c|c|c|}
\hline \multirow{2}{*}{ Karakter Agronomi } & \multirow{2}{*}{ Peubah bebas yang di bakukan } & \multirow{2}{*}{ Pengaruh langsung } & \multicolumn{2}{|c|}{ Pengaruh tidak langssung } & \multirow{2}{*}{ Total } & \multirow{2}{*}{ Selisih } \\
\hline & & & $\mathrm{Z1}$ & $\mathrm{Z} 2$ & & \\
\hline JBPP & $\mathrm{Z1}$ & 0.968 & & 0.031 & 0.999 & 0.031 \\
\hline IP & $\mathrm{Z2}$ & 0.035 & 0.866 & & 0.900 & 0.866 \\
\hline
\end{tabular}

Keterangan:

1. Pengaruh langsung yang ditunjukkan dalam analisis lintas dapat langsung dibandingkan untuk mengetahui peranan dari setiap karakter dalam mempengaruhi karakter BBPP

2. Karakter :
JBPP
Jumlah buah per anak petak
IP

Indeks panen 
Diagram lintas digunakan untuk lebih memperjelas uraian analisis lintas yang dikemukakan (Gambar 1). Dengan mengkombinasikan diagram-diagram geometrik dan persamaan-persamaan aljabar, maka analisis statistika dalam mempelajari hubungan kausal-efek diantara variabel-variabel menjadi lebih berbobot dalam arti hasilnya menjadi lebih mudah untuk dipahami. Diagram lintas di susun berdasarkan pengetahuan yang mendasari tentang hubungan kausal berdasarkan hipotesis yang dibuat (Singh dan Chaudhary 1985)

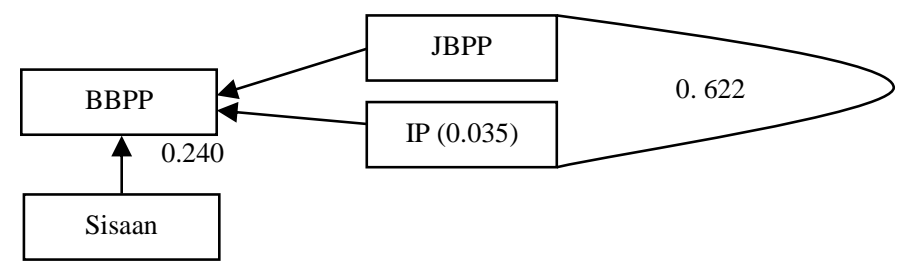

Gambar 1. Diagram lintas karakter kuantitatif pada galur-galur harapan kacang tanah (Arachis hypogaea L.) rakitan IPB

Diagram lintas dapat menjelaskan bahwa besaran sisaan sebesar 0,240 dapat diinterpretasikan sebagai model analisis lintas tidak mampu menjelaskan pengaruh-pengaruh lain diluar pengaruh variabel bebas yang dibakukan sebesar 0.240 atau sebesar $0.24 \%$. Dengan kata lain, pengaruh sisa yang tidak dapat dijelaskan oleh model adalah sebesar 0,240 atau $4 \%$. Hal ini berarti model analisis lintas mampu menjelaskan total keragaman dalam bobot biji kering sebesar $1-\mathrm{C}^{2}{ }_{\mathrm{s}}=1-0.240=0.76$ atau $76 \%$

Upaya dalam menentukan karakter-karakter yang dapat dijadikan kriteria seleksi yang efektif dapat dilihat dari besarnya pengaruh langsung, korelasi antar karakter dan selisih antar korelasi antara peubah bebas dan pengaruh langsung peubah tersebut (Yunianti et al. 2010). Dengan demikian karakter yang sesuai dengan kriteria seleksi yang efektif adalah jumlah buah per tanaman dan indeks panen. Kedua karakter tersebut memiliki nilai pengaruh langsung positif, bertanda sama dengan nilai korelasi dan memiliki selisih yang kecil.kedua karakter tersebut dapat digunakan sebagai kriteria seleksi secara tidak langsung pada tanaman tomat.

\section{Simpulan}

Analisis lanjut menggunakan korelasi dan analisis lintas dari data tomat menunjukkan bahwa jumlah buah per anak petak dan indeks panen merupakan karakter yang mempunyai pengaruh langsung yang positif, bertanda sama dengan nilai korelasi serta memiliki selisih yang kecil dan dapat dijadikan sebagai kriteria seleksi dalam pemuliaan tanaman tomat.

Pustaka

Allard, R.W. 1960. Principles of Plant breeding. John Wiley and Sons, Inc. $485 \mathrm{p}$.

Ambarwati, E., \& Murti, R. H. (2001). Analisis korelasi dan koefisien lintas sifat-sifat agronomi terhadap komposisi kimia umbi iles-iles (Amorphophallus variabilis) $=$ Correlation and path coefficient analysis of agronomic traits on chemical compositions... Ilmu pertanian, 8(2001).

Arshad, M., Aslam, M., \& Irshad, M. (2009). Genetic variability and character association among morphological traits of mungbean, Vigna radiata L. Wilczek genotypes. Journal of Agricultural Research, 47(2).

Falconer DS, Mackay TFC. 1996. Introduction to Quantitative Genetics. England (DE): Longman.

Gani A, Suhartono, Rukidjo. 1995. Evaluasi sifat-sifat penentu hasil kacang tanah (Arachis hypogaea L.) di lahan podzolik merah kuning. Pem. Penel. Sukarami 24: 12-17.

Gomez KA, Gomez AA. (1995). Statistical Procedures for Agricultural Research. Philippines (PH): International Rice Research Institute, Los Banos, Laguna.

Haydar, A., Mandal, M. A., Ahmed, M. B., Hannan, M. M., Karim, R., Razvy, M. A., ... \& Salahin, M. (2007). Studies on genetic variability and interrelationship among the different traits in tomato (Lycopersicon esculentum Mill.). Middle-East Journal of Scientific Research, 2(3-4), 139142 .

Li, C. C. (1956). The concept of path coefficient and its impact on population genetics. Biometrics, 12(2), 190-210.

Mattjik AA, Sumertajaya IM. 2006. Perancangan Percobaan dengan Aplikasi SAS dan MINITAB. Edisi pertama. Bogor (ID): IPB Press

Mohammadi, S. A., Prasanna, B. M., \& Singh, N. N. (2003). Sequential path model for determining interrelationships among grain yield and related characters in maize. Crop science, 43(5), 1690-1697.

Nasution MA. 2010. Analisis korelasi dan sidik lintas antara karakter morfologi dan Komponen buah tanaman nenas (Ananas comosus L. Merr.) Crop Agro. Vol.3 No.1 - Januari 2010.

Priyatno, D. 2009. 5 Jam Belajar Olah Data dengan SPSS 17. Yogyakarta (ID): Kanisius

Rahman AKM, Nag BL, Miah MA. 2002. Correlation and path analysis of seed yield in mungbean. Journal Agricultural Research 27: 305-308
Singh RK, Chaudhary BD. 1979. Biometrical Methods in Quantitative Genetic Analysis. Revised Edition. New Delhi (IN): Kalyani Publ.

Singh RK, Chaudhary BD. 1985. Biometrical methods in quantitative genetics analysis. New Delhi (IN): Kalyani Publisher.

Siregar S. 2013. Statistik Parametrik untuk Penelitian Kuantitatif. Jakarta (ID): Bumi Aksara.

Sugiyono. 2003. Statistik untuk Penelitian. Bandung (ID): Alfabeta

Wirnas D, Widodo I, Sobir, Trikoesoemaningtyas, Sopandie S. 2006. Pemilihan karakter agronomi untuk menyusun indeks seleksi pada 11 populasi kedelai generasi F6. Bul Agron. 34(1)19-24.

Walpole RE. 1993. Pengantar Statistika Edisi ke-3. Jakarta (ID): Gramedia Pustaka Utama

Yunianti, R., Sastrosumarjo, S., Sujiprihati, S., Surahman, M., \& Hidayat, S. H (2010). Kriteria seleksi untuk perakitan varietas cabai tahan Phytophthora capsici Leonian. Jurnal Agronomi Indonesia (Indonesian Journal of Agronomy), 38(2). 